\title{
Peran Pola Asuh Permisif, Iklim Sekolah, dan Motivasi Berprestasi Terhadap Perilaku Membolos Siswa
}

\author{
Salwa Muin \\ Universitas Muhammadiyah Maluku Utara \\ Jl. KH, Ahmad Dahlan No. 100, Sasa, Ternate Selatan, Indonesia \\ Email: salwa.muin@gmail.com
}

\begin{abstract}
This research aims to the role of permissive parenting, school atmosphere, and achievement motivation towards students' truant behavior. This is a correlational research. The quantitative approch is used in this research. The participants were 200 students of SMK PIRI 1 Yogyakarta. There was a form of scale of truant behavior, permissive parenting, school atmosphere and achivement motivation that used as the instrument of this research. The data were analyzed using multiple regression analysis. Based on the analysis results, the obtained data showed a coefficient of 22.044 with the sig. 0,000 . The results of the study showed that there is a significant influence between permissive parenting towards students' truant behavior, school atmosphere and achievement motivation by $25,2 \%$. Specifically, there is a significant influence between permissive parenting towards students' truant behavior by $18,3 \%$, there is no significant influence between school atmosphere towards students' truant behavior by $1,6 \%$, there is a significant influence between achievement motivation towards students' truant behavior by $24,5 \%$. This research findings can be considered as useful information for the parents in order to provide an effective parenting for their children. On the other hand, these findings can be used as the ponder in developing guidance and counseling services to reduce students' truant behavior.
\end{abstract}

Keywords: truant behavior, permissive parenting, school atmosphere, achievement motivation

Penelitian ini bertujuan untuk mengetahui peran pola asuh permisif, iklim sekolah, dan motivasi berprestasi terhadap perilaku membolos siswa. Penelitian ini menggunakan pendekatan kuantitatif dengan jenis penelitian korelasi. Subjek penelitian sejumlah 200 siswa SMK PIRI 1 Yogyakarta. Instrumen yang digunakan berupa skala perilaku membolos, pola asuh permisif, iklim sekolah, dan motivasi berprestasi. Analisis data yang digunakan adalah analisis regresi berganda. Berdasarkan hasil analisis data diperoleh koefisien sebesar 22,044 dengan sig. 0,000. Hasil penelitian menunjukkan adanya pengaruh yang sangat signifikan antara pola asuh permisif, iklim sekolah dan motivasi berprestasiterhadap perilaku membolos siswa dengan persentase $25,2 \%$. Secara spesifik terdapat pengaruh yang sangat signifikan antara polah asuh permisif terhadap perilaku membolos dengan persentase $18,3 \%$, tidak ada pengaruh yang signifikan antara iklim sekolah terhadap perilaku membolos dengan persentase $1,6 \%$, dan ada pengaruh yang signifikan antara motivasi berprestasi terhadap perilaku membolos dengan persentase $24,5 \%$. Hasil penelitian ini dapat dijadikan sebagai informasi bagi orangtua dalam memberikan pola asuh yang efektif bagi anak. Bagi guru bimbingan dan konseling dapat dijadikan sebagai bahan pertimbangan dalam menyusun program layanan bimbingan dan konseling untuk mereduksi perilaku membolos siswa.

Kata kunci:perilaku membolos, pola asuh permisif, iklim sekolah, motivasi berprestasi

\section{Pendahuluan}

Masa remaja merupakan masa yang penuh gejolak emosi dan ketidakseimbangan. Informasi global yang diterima oleh remaja sangat cepat dan tanpa ada penyaring pada dirinya sehingga banyak remaja mengembangkan pola tingkah laku yang menyimpang dari norma-norma umum atau berbuat semaunya sendiri yang dapat mengganggu atau merugikan orang lain. Pada usia remaja sebaiknya penanaman nilai-nilai moral harus dipertahankan.
Masa remaja masih merupakan masa untuk belajar disekolah. Pelanggaran peraturan sekolah oleh remaja merupakan suatu problem yang dihadapi oleh pihak sekolah. Pelanggaranpelanggaran yang sering terjadi di lingkungan sekolah dalam kehidupan remaja sehari-hari misalnya pelajar terlambat datang kesekolah, merokok, dan membolos. Sarwono (2012) menyebutkan bahwa membolos merupakan salah satu bentuk dari kenakalan remaja yaitu kenakalan yang melawan status, misalnya mengingkari status anak sebagai pelajar dengan 


\section{PERILAKU MEMBOLOS, POLA ASUH PERMISIF, IKLIM SEKOLAH, MOTIVASI BERPRESTASI}

cara membolos. Membolos juga dikatakan sebagai masalah perilaku negatif yang menyimpang yang ditunjukan siswa berupa tidak masuk sekolah, membolos atau pulang sekolah sebelum waktunya, dan sering keluar kelas pada jam pelajaran (Supriadi, 2014). Tindakan membolos dikedepankan sebagai sebuah jawaban atas kejenuhan yang sering dialami oleh banyak siswa terhadap kurikulum sekolah. Pelajar yang membolos bukan hanya disalah satu sekolah saja tetapi banyak sekolah mengalami hal yang sama. Tentunya hal ini dapat merugikan dirinya, sebab membolos yang dilakukan siswa merupakan bentuk kagagalan yang ditunjukkan siswa dalam belajar (Ellena, 2014).

Hasil penelitian Damayanti (2013) di kota Surabaya menunjukan 59,6\% siswa pernah membolos dan sisanya 40,6\% mengatakan tidak pernah membolos. Pernyataan para siswa juga diperteguh temuan tersebut dengan persentase data yang sedikit berbeda, yakni siswa yang membolos sekolah sebesar $53,6 \%$ dan sisanya $46,4 \%$ menyatakan tidak pernah membolos. Alasan-alasan dibalik perilaku mebolos cukup beragam seperti karena malas, ada keperluan, guru yang tidak enak mengajar, jam pelajaran kosong dan mencari perhatian. Ketika membolos siswa biasanya keluyuran ditempat-tempat hiburan dan pusat perbelajaan. Hal ini dibuktikan dengan kasus tujuh siswa SMP dan SMA di Bantul Yogyakarta terjaring razia di warung kopi pada saat jam pelajaran berlangsung di sekolah. Menurut keterangan Kapolsek siswa-siswa tersebut berpamitan dengan orang tua ke sekolah tetapi nyata tidak sampai kesekolah (www.jogja.solopos.com). Selain itu dalam penertiban di kota Yoyakarta tertangkap seorang pelajar ketahuan membawa benda tajam, sementara itu ditemukan juga dua pelajar yang diketahu membolos saat jam pelajaran, saat ditanggap pelajar tesebut sedang bermain game online di warnet (www.kabarkota.com).

Fenomena membolos juga terjadi di SMK PIRI 1 Yogyakarta. Berdasarkan observasi dan wawancara terhadap seorang guru bimbingan dan konseling di SMK Piri 1 Yogyakarta pada tanggal 26 Febuari 2015, perilaku membolos yang sering dilakukan siswa SMK PIRI 1 Yogyakarta yaitu, membolos pada jam pelajaran. Siswa sering kali kedapatan di kantin atau di belakang sekolah pada jam pelajaran berlangsung, dan siswa yang tidak masuk sekolah tanpa keterangan (izin). Upayaupaya telah dilakukan oleh pihak sekolah tetapi masih ada juga siswa yang berperilaku demikian.

Berdasarkan fenomena yang ada, perilaku membolos yang dilakukan siswa merupakan salah satu bentuk dari kenakalan siswa yaitu ketidakdisiplinan dan ketidakjujuran serta kebiasaan buruk. Prayitno (2009) mengatakan bahwa pelajar yang membolos akan berdampak negatif pada dirinya yaitu ketinggalan pelajaran, minat belajar yang kurang, gagal dalam hasil ujian, hasil belajar yang diperoleh tidak sesuai dengan potensi yang dimiliki, tidak naik kelas, pengasaan materi akan tertinggal dengan temantemannya, dan bahkan dapat dikeluarkan dari sekolah. Selain itu membolos juga dipercaya dapat menimbulkan masalah kriminalitas seperti tawuran antar sekolah, ngebut-ngebutan dijalan raya, pencurian dan perampokan (Indayani, 2014).

Mengingat dampak buruk yang terjadi akibat dari perilaku tersebut, perilaku membolos yang dilakukan siswa tentunya dipengaruhi oleh banyak faktor. Menurut Kearney (2001) dalam penelitiannya menyebutkan bahwa terdapat tiga faktor penyebab siswa membolos yaitu faktor personal terkait dengan menurunya motivasi atau hilangnya minat akademik siswa, ketinggalan pelajaran, dan minum minuman alkohol atau minuman keras. Sedangkan faktor sekolah terkait dengan kebijakan mengenai pembolosan yang tidak konsisten, minimnya hubungan orang tua dengan sekolah, dan guru-guru yang kurang sportif, serta tugas-tugas sekolah yang kurang menantang bagi siswa, sedangkan faktor keluarga terkait dengan pola asuh orang tua atau kurangnya partisipan dari orang tua. Shepparrd (2009) dalam penelitian menyatakan perilaku membolos remaja disebabkan karena pola asuh orang tua yaitu kurangnya perhatian dan dukungan yang ditunjukan orang tua terhadap pendidikan anakanaknya.

Keluarga merupakan unit yang paling inti dalam memberikan interaksi dan hubungan antara anggotanya. Sebagai pendidik dan pengasuh, orang tua memiliki tugas peduli dan bertanggungjawab penuh untuk memelihara dan mendisiplinkan anak-anak mereka. Anak-anak yang dibesarkan dalam lingkungan keluarga yang sedikit sekali atau tanpa mendapatkan penagawasan latihan yang disiplin dan teratur, 
tidak akan sanggup menginternalisasikan dalam dirinya norma-norma hidup dan susila yang ada, bahkan banyak diantara mereka kebal terhadap nilai kesusilaan, sebaliknya mereka menjadi lebih peka terhadap pengaruh-pengaruh yang negatif dari luar.

Salah satu pengasuhan dalam keluarga yang mendidik anak secara bebas, anak diberikan kelonggran untuk melakukan apa saja yang dikehendaki, kontrol terhadap anak yang sangat lemah, dan juga kurangnya bimbingan yang cukup berarti bagi anak adalah pola pengasuhan orang tua yang permisif. Mahmuda (2013), mengatakan bahwa orang tua yang permisif kurang membimbing anak dan membentuk tingkah laku anak, orang tua membiarkan anak meraba-raba dalam situasi sulit orang tua membiarkan remaja mengambil keputusan sendiri menurut kehendak sendiri. Iqbo (2005) menyebutkan bahwa masalah disiplin dan prestasi akademik yang buruk yang menyebabkan siswa tidak datang kesekolah disebabkan dari orang tua. Penelitian lain menyebutkan bahwa presepsi siswa terhadap pola asuh permisif orang tua berpengaruh terhadap perilaku membolos siswa disekolah (Paramitasari, 2012).

Intervensi orang tua dan sekolah sangatlah penting untuk mengontrol perilaku siswa disekolah. Gonzales (Trujillo, 2006) menganggap pembolosan yang dilakukan remaja disebabkan oleh iklim sekolah. Iklim sekolah meliputi termasuk guru, kebijakan sekolah yang tidak konsisten, sarana fisik telah terbukti mempengaruhi keinginan siswa untuk datang ke sekolah (membolos).

Austin (2014), menegaskan bahwa hubungan sekolah dengan keterlibatan siswa disekolah yaitu terkait dengan Iklim sekolah yang membina hubungan antara siswa dan staf, rasa aman, fisik, emosional, dan adanaya dukungan yang dapat memenuhi kebutuhan fasilitas yang berkaiatan dengan perkembanagan sosial emosi, kesehatan, dan akademis siswa. iklim sekolah, termasuk guru, kebijakan sekolah, sarana fisik, telah terbukti mempengaruhi keinginan siswa untuk datang ke sekolah. Penelitian lain menyebutkan bahwa persepsi siswa terhadap sekolah sangat mempengaruhi siswa dalam merasakan lingkungan kelas dan merupakan penentu hubungan anak-anak untuk hadir disekolah Gonzales (Trujillo, 2006).
Iklim sekolah sekolah yang kondusif akan mempengaruhi perilaku menyimpan pada siswa. Siswa yang memiliki motivasi belajar yang rendah merasa cepat bosan berada disekolah, hal ini membuat siswa untuk mevari hal-hal yang baru di luar sekolah akhirnya anak akan menunjukan perilaku menyimpan. Untuk itu motivasi sangat diperlukan dalam proses belajar karena motivasi sebagai pendorong dari dalam diri siswa untuk mencapai prestasi.

Reid (2004) mengaitkan pentinganya motivasi bagi pelajar untuk tetap berprestasi dalam pendidikanya dalam rangka menekan angka membolos pelajar. Motivasi sangat diperlukan dalam proses belajar. Motivasi merupakan daya dorong dari dalam diri siswa untuk mencapai prestasi. Dengan demikian motivasi berprestasi merupakan manifestasi dari keinginan yang dapat mempengaruhi perilaku untuk melakukan yang terbaik dalam aktivitas pendidikannya. Siswa yang memiliki motivasi berprestasi yang tinggi akan menimbulakan kegiatan belajar yang menjamin kelangsungan dalam kegiatan belajar dan memberi arahan sehingga tujuan yang dikehendaki oleh siswa dapat tercapai dengan hasil sebaik-baiknya. Dengan adanya motivasi berprestasi, maka akan melahirkan prestasi yang baik. Sebaliknya Seorang siswa dengan motivasi prestasi yang rendah memiliki sebuah keyakinan bahwa tanpa harus berprestasi dan unggul dibandingkan dengan orang lain, dirinya bisa memperoleh apa yang dia inginkan dan biasanya siswa tersebut tidak membutuhkan sebuah kesuksesan atau keberhasilan. Aktifitas sekolah hanya akan menjadi sebuah belenggu bagi kebebasannya sehingga ketika mereka harus bolos maka tidak ada ancaman semacam beban buatnya.

Dorcas (2013), dalam kesimpulan penelitiannya mengatakan bahwa bolos dapat menghambat pembelajaran yang efektif, dan bolos dapat mengakibatkan prestasi akdemik yang rendah. Reid (2006), menganggap membolos adalah dampak dari rendahnya motivasi berprestasi, rendahnya sopan santun, pemasalahan perilaku dan status ekonomi. Bazemore, Stinchcomb, dan Leip (2004), mengemukakan bahwa pentingnya meningkatkan motivasi berprestasi pada siswa dengan cara meningkatkan komunkasi antara sekolah dan orang tua yang akan sangat berpengaruh dalam rangka 

BERPRESTASI

menurunkan angka membolos pelajar dari sekolah.

Berdasarkan uraian yang telah dijelaskan, maka tujuan dari penelitian ini adalah mengetahui peran pola asuh permisif, iklim sekolah, dan motivasi berprestasi dengan perilaku membolos siswa pada siswa-siswi SMK PIRI 1 Yogyakarta. Perilaku membolos penting untuk diketahui agar dapat dilakukan upaya untuk mereduksi perilaku membolos di sekolah, baik bagi orangtua maupun guru. Upaya yang dapat dilakukan oleh orangtua dengan menerapkan pola asuh yang tepat bagi anak. Selain itu, upaya yang dapat dilakukan guru di sekolah yaitu dengan menciptakan iklim sekolah yang nyaman bagi siswa untuk belajar dan membantu menumbuhkan motivasi berprestasi agar siswa mampu bersaing dalam bidang akademik. Hasil penelitian ini dapat dijadikan sebagai informasi bagi orangtua dalam memberikan pola asuh yang efektif bagi anak. Bagi guru bimbingan dan konseling dapat dijadikan sebagai bahan pertimbangan dalam menyusun program layanan bimbingan dan konseling untuk mereduksi perilaku membolos siswa.

\section{KajianLiteratur}

\section{Perilaku Membolos}

Perilaku manusia pada dasarnya tidak terlepas dari keadaan individu itu sendiri dan lingkungan dimana individu itu berada. Menurut Kamus Besar Bahasa Indonesia, perilaku identik dengan tingkah laku. Perilaku adalah tanggapan atau reaksi individu terhadap rangsangan atau lingkungan. Jadi dari pengertian tersebut dapat disimpulkan bahwa perilaku merupakan reaksi seseorang individu terhadap adanya stimulus guna tercapainya suatu tujuan.

Membolos dapat diartikan sebagai perilaku siswa yang tidak masuk sekolah dengan alasan yang tidak tepat atau membolos juga dikatakan sebagai ketidak hadiran tanpa adanya suatu alasan yang jelas (Indayani, 2014). Pengertian lain menyebutkan bahwa perilaku membolos dapat diartikan sebagai tanggapan atau reaksi individu yang terwujud dalam gerakan meninggalkan pelajaran saat pelajaran berlangsung dan tidak mengikuti proses belajar mengajar disekolah atau absen (Mahmuda, 2012).
Berdasarkan pendapat teori di atas maka yang dimaksud dengan perilaku membolos adalah tanggapan atau reaksi individu yang terwujud dalam perilaku meninggalkan sekolah saat pelajaran berlangsung dan tidak mengikuti proses belajar mengajar di sekolah tanpa izin, baik dari jam tertentu maupun satu hari penuh. Menurut Prayitno \& Amti (2009), bentuk perilaku membolos yaitu berhari-hari tidak masuk sekolah, tidak masuk sekolah tanpa izin, sering keluar pada jam pelajaran tertentu, tidak masuk kembali pada jam pelajaran tertentu. tidak masuk kembali setelah minta izin, mengajak teman-teman untuk keluar pada mata pelajaran yang tidak disenangi, minta izin keluar dengan pura-pura sakit atau alasan lain, mengirimkan surat izin tidak masuk dengan alasan yang dibuat-buat, dan tidak masuk kelas lagi setelah jam istirahat.

\section{Pola Asuh Permisif}

Pola asuh permisif adalah suatu pola asuh yang kurang membimbing dan mengarahkan anak, anak diberikan kebebasan sepenuhnya untuk berbuat semaunya tanpa ada kontrol dari orang tua. Bee dan Boyd (2007) menyebutkan pola asuh permisif yaitu pola asuh yang didalamnya ada kehangatan dan toleran terhadap anak, orang tua tidak memberikan batasan, kurang menuntut, kurang mengontrol, dan cenderung kurang berkomunikasi.

Menurut Santrock (2002) pola asuh permisif dibagi menjadi dua yaitu Permissive indifferent dan permissive indulgent.Permissive indifferent adalah suatu pola asuh dimana orang tua sangat tidak terlibat dalam kehidupan anak, tipe pengasuhan ini diasosiasikan dengan inkompetensi sosial anak, khususnya kurangnya kendali diri.Permissive indulgent adalah pola asuh dimana orang tua sangat terlibat dalam kehidupan anak-anak mereka tetapi menetapkan sedikit batas atau kendali terhadap mereka. Pengasuhan ini diasosiasikan dengan inkompetensi sosial anak. Orang tua macam ini membiarkan anak melakukan apa yang ia inginkan.

Hurlock (1997) mengemukakan bahwa aspek-aspek pola permisif yaitu :

1. Kontrol terhadap anak kurang, yaitu berkaitan dengan tidak adanya pengarahan perilaku anak sesuai dengan norma 
masyarakat, serta orang tua yang tidak menaruh perhatian dengan siapa saja anak bergaul.

2. Orang tua yang masah bodoh, yaitu berkaitan mengenai kebebasan anak untuk memilih sekolah sesuai dengan keinginan anak, orang tua tidak memberikan teguran disaat anak berbuat kesalahan, dan kurang memperhatikan pendidikan moral dan agama.

3. Pendidikan yang bersifat bebas, yaitu berkaitan dengan kurangnya keperdulian orang tua terhadap anak, orang tua tidak bemberikan hukuman saat anak sedang melakukan tindakan yang melanggar norma.

4. Anak yang mengabaikan keputusan orang tua. Mengenai memberikan anak untuk memutuskan segala segala sesuatu sendiri, tanpa adanya pertimbangan dengan orang tua.

\section{Iklim Sekolah}

Umaroh (2014), mendefinisikan Iklim sekolah sebagai keadaan atau kualitas lingkungan sekolah yang didasarkan pada pengalaman siswa selama belajar dan berinteraksi dengan seluruh masyarakat sekolah terutama dengan guru dan sesama siswa. Sedangkan menurut Haward et.al (1974), iklim sekolah sebagai keadaan sosial dan budaya sekolah itu mempengaruhi tingkah laku orang didalamnya. kualitas dan karakter dari kehidupan sekolah yang merefleksikan beberapa hal antra lain; norma tujuan, nilai, hubungan interpersonal, proses belajar mengajar, kepemimpinan dan struktur organisasi.

Nurdin (2014) menyatakan terdapat tiga pengertian iklim sekolah, yaitu pertama, iklim sekolah diartikan sebagai ciri-ciri sekolah yang membedakannya dengan sekolah lainnya. Kedua, iklim sekolah diartikan sebagai suasana ditempat kerja, mencakup norma yang kopleks, nilai, harapan, kebijaksanaan dan prosedur yang mempengaruhi pola perilaku individu dan kelempok. Dan ketiga, iklim sekolah diartikan sebagai persepsi individu terhadap kegiatan, amalan dan prosedur serta persepsi tentang tingkahlaku yang dihargai, didukung dan diharapkan dalam organisasi.

Berdasarkan pendapat definisi iklim sekolah di atas, dapat di simpulkan bahwa iklim sekolah adalah suasana atau keadaan lingkungan sekolah yang didalamnya meliputi interaksi, norma tujuan, nilai, proses belajar mengajar dan hubungan interpersonal yang dapat menciptakan suatu perasaan yang aman, nyaman serta merasah memiliki terhadap segala sesuatu disekitar lingkungan sekolah.

Menurut Mondark (Usman, 2013) mengemukakan tentang aspek-aspek ilkim sekolah sebagai berikut:

1. Lingkungan belajar yaitu persepsi dari para siswa tentang konteks pembelajaran dan siswa belajar keras serta aspek atas apa yang di lakukannya dalam proses pembelajaran. Dukungan dari guru dalam proses pembelajaran akan meningkatkan motivasi siswa dalm belajar. Semakin baik iklim lingkungan belajar maka akan tercipta suana yang kondusif dalam proses belajar mengajar, sehingga siswa akan merasa nyaman dalam belajar.

2. Lingkungan fisik dan sosial yaitu persepsi siswa tentang kebersihan sekolah, manajemen atau perilaku yang baik yang tercipta di dalam maupun di luar kelas serta hubungan interpersonal guru dan siswa yang baik akan menciptakan suasana atau iklim sekolah baik.

3. Hubungan antara rumah dan sekolah yaitu hubungan antara sekolah dengan orang tua. Terciptanya hubungan dengan baik sekolah dan rumah akan membuat siswa merasa aman dan nyaman dalam melakukan aktivitas pembelajaran di sekolah.

4. Keamanan sekolah yaitu sejauh mana siswa merasa aman dan nyaman dengan lingkungan sekolah. Siswa yang merasa aman di sekolah akan mempengaruhi performansi akademik, perilaku, sosioemosional, dan kesejahteraan psikologis.

\section{Motivasi Berprestasi}

Menurut Gunarsa (1994), motivasi beprestasi adalah sesuatu yang ada dan dibawa dari lahir, yang kemudian ditumbuhkan dan dikembangkan melalui interaksi dengan lingkungan. Pendapat lain menyebutkan bahwa motivasi berprestasi merupakan dorongan untuk menguasai, memanipulasi, mengatur lingkungan sosial atau fisik, mengatasi rintangan, dan memelihara 

BERPRESTASI

kualitas kerja yang tinggi, bersaing untuk melebihi perbuatan yang lampau dan mengungguli orang lain (Atkison, 1992).

Santrock (2001) mengatakan motivasi beprestasi adalah keinginan dan dorongan individu untuk mengerjakan sesuatu dengan hasil baik. Winkel (1991) motivasi berprestasi pada siswa menengah merupakan daya penggerak dalam diri siswa untuk mempercepat taraf prestasi belajar setinngi munkin demi penghargaan kepada diri sendiri. Apabila taraf prestasi siswa itu tercapai, maka siswa akan merasa puas, memberikan pujian pada diri sendiri, dan apabila prestasi siswa tidak tercapai maka siswa akan merasa kecewa dan cenderung mencela diri sendiri. Hasrat untuk berprestasi yang baik tersebut bukan menurut ukuran orang lain melainkan menurut ukran sendiri-sendiri.

Menurut Thoha (1994) motivasi berprestasi dipengaruhi oleh faktor kebutuhan, yaitu kebutuhan yang ada didalam setiap individu untuk bersaing, suatu kebutuhan yang sudah terpuaskan akan berlanjut pada kebutuhan yang lain. Sedangkan menurut Sadirman (1996) faktor lain yang mempengaruhi motivasi berprestasi adalah minat. Minat diartikan sebagai suatu kondisi dimana individu melihat ciri-ciri yang dihubungkan dengan keinginan, minat biasanya disertai dengan rasa senang karena biasanya berkaitan dengan sesuatu yang dituju atau dicapai.

Menurut Asnawi (2002) empat aspek yang membedakan tingkat motivasi berprestasi individu yaitu:

1. Mengambil tanggung jawab atas tanggung jawabnya

Individu dengan motivasi berprestasi tinggi merasa dirinya bertanggung jawab atas tugas yang di kerjakannya. Seseorang akan berusaha untuk menyesuaikan setiap tugas yang di lakukan dan tidak akan meninggalkannya sebelum menyelaikanya

2. Memperhatikan umpan balik terhadap perbuatannya

Pada individu yang mempunyai motivasi berprestasi tinggi, pemberian umpan balik atas usaha kerjanya yang telah di lakukan sangat disukai dan berusaha untuk melakukan perbaiakan hasil kerja yang akan datang.
3. Mempertimbangkan resiko

Individu dengan motivasi berprestasi tinggi cenderung mempertimbangkan terhadap resiko yang dihadapinya sebelum memulai pekerjaan. Ia akan memilih tugas dengan derajat sedang, yang menantang kemampuanya, namun masih memungkinkan untuk berhasil menyelesaikan dengan baik.

4. Kreatif - Inovatif

Individu dengan motivasi berprestasi tinggi cenderung bertindak kreatif, dengan mencari cara baru untuk menyelesaikan tugas seefektif dan seefisien mungkin.

\section{Metode Penelitian}

Penelitian ini menggunakan pendekatan kuantitatif dengan jenis penelitian korelasi. Adapun subjek penelitian adalah siswa-siswi SMK PIRI 1 Yogyakarta tahun ajaran 2014/2015 dengan jumlah subyek 200 siswa. Instrumen yang digunakan dalam penelitian ini berupa skala dan menggunakan analisis regresi berganda tiga prediktor yang terdapat pada SPSS versi 19. Analisis digunakan untuk mengungkap pengaruh antara pola asuh permisif, iklim sekolah, dan motivasi berprestasi terhadap perilaku membolos.

\section{Hasil Penelitian dan Pembahasan}

Hasil penelitian ini menunjukan bahwa adanya pengaruh yang sangat signifikan darivariabel pola asuh permisif, iklim sekolah dan motivasi berprestasi terhadap terhadap perilaku membolos siswa. Berdasarkan analisis regresi berganda menggunakan SPSS 19 for windows. Diperoleh koefisien sebesar 22,044 dengan sig. 0,000. Degan sumbangan efektif dari variabel independen pola asuh permisif, iklim sekolah, dan motivasi berprestasi terhadap perilaku membolos siswa 0,252 atau $25,2 \%$. Dengan demikian analisis dari penelitian ini diterima dengan adanya hubungan yang sangat signifikan antara pola asuh permisif, iklim sekolah dan motivasi berprestasi terhadap perilaku membolos siswa.

Berdasarkan analisis secara parsial, terdapat pengaruh yang sangat signifikan antara pola asuh permisif terhadap perilaku membolos siswa 
dengan nilai $\mathrm{t}=6,452$, sehingga disimpulkan ada pengaruh positif yang signifikan antara pola asuh permisif terhadap perilaku membolos siswa. Dimana pengaruh variabel pola asuh permisif terhadap perilaku membolos yaitu sebesar 0,407 atau sebesar 18,3\% sedangkan sumbangan relatif pola asuh permisif terhadap perilaku membolos sebesar $72,6 \%$.

Hasil penelitian Sheppard mengatakan bahwa salah satu faktor yang mempengaruhi perilaku membolos siswa berasal dari faktor keluarga yaitu meliputi pola asuh orang tua, dimana kurangnya perhatian dan dukungan yang ditunjukan oleh orang tua terhadap pendidikan anaknya. Keluarga merupakan unit yang paling inti dalam memberikan interaksi dan hubungan antara anggotanya. Sebagai pendidik dan pengasuh, orang tua memiliki tugas peduli dan bertanggung jawab untuk memelihara dan mendisiplinkan anak-anaknya. Salah satu faktor utama dalam keluarga yang mempunyai peran penting dalam pembentukan kepribadian adalah praktik pengasuhan anak. Akan tetapi pada kenyataanya banyak orang tua yang mengabaikan perannya sebagai orang tua dalam membimbing dan mengarahakan perilaku anakanaknya seperti pola pengasuhan yang permisif.

Joshi dan Acharya (2013) menjelaskan bahwa permisif meliputi pemberian kesempatan kepada anak-anak untuk mengekspresikan pandangannya dengan bebas, berindak sesuai dengan keinginannya, bebas bertindak semaunya tanpa kesimpulan orang tua. Sedangkan pada usia sekolah remaja masih sangat membutuhkan bimbingan orang tua. Pada usia remaja banyak aspek yang membutuhkan bimbingan orang tua, apalagi pada saat anak mengambi keputusan. Yusuf (2007) mengatakan bahwa anak yang dibesarkaan dalam pola asuh permisif akan memiliki karakter yang inplusif, agresif, tidak patuh, kurang mandiri, atau menang sendiri, kurang percaya diri dan kurang matang. Sehingga menimbulkan kesulitan saat anak menghadapi peraturan dalam lingkungan sosial.

Berdasarkan hasil kategorisasi skor subjek terhadap skala pola asuh pemisif menunjukan bahwa hampir seluruh siswa termasuk dalam kategori sedang yaitu 159 atau 75,9\% berada dalam kategori sedang, 41 siswa 20,5\% berada dalam kategori tinggi. Kondisi ini menunjukan bahwa sebagian besar presepsi subjek penelitian terhadap pola asuh permisif orang tua dalam kategori sedang, dan sebagian lagi cenderung tinggi. Dari hasil tersebut peneliti menduga bahwa perilaku membolos subjek yang tinggi disebabkan oleh presesi pola asuh permisif yang tinggi. Bukan tidak mungkin ketika siswa mempresepsikan orang tua yang memberikan kebebasan dan cenderung tidak perduli serta tidak memperhatikan apapun yang dilakukan maka akan timbul keinginan untuk berbuat sesuka hatinya sekaligus munculkan sikap negatif pada siswa untuk suka membolos sekolah. Hasil tersebut dapat dilihat pada Gambar 1.

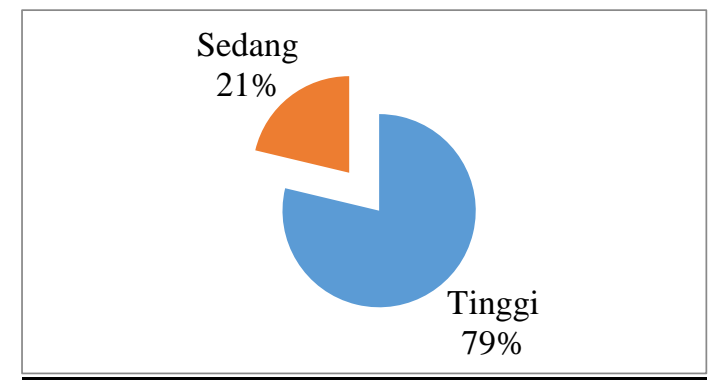

Gambar 1. Hasil kategorisasi skor subjek terhadap skala pola asuh permisif

Berdasarkan analisis secara parsial, terdapat pengaruh yang tidak signifikan antara iklim sekolah terhadap perilaku membolos siswa yaitu nilai sig. $=0,006>(0,05)$. Besar kontribusi iklim sekolah terhadap perilaku membolos yaitu $1,6 \%$. Berdasarkan hasil kategorisasi skor subjek terhadap skala iklim sekolah menunjukan bahwa hampir seluruh siswa termasuk dalam kategori sedang yaitu 164 siswa atau $80 \%$ berada dalam kategori sedang, 35 siswa 17,5\% berada dalam kategori tinggi, dan 1 siswa atau $5 \%$ berada dalam kategori rendah. Kondisi ini menunjukan bahwa sebagian besar presepsi subjek penelitian terhadap iklim sekolah dalam kategori sedang. Hasil tersebut menunjukan bahwa sebagian besar subjek mempresepsikan bahwa sekolah adalah lingkungan yang baik bagi siswa dalam menuntut ilmu. Hal tersebut dapat dilihat pada Gambar 2. 

BERPRESTASI

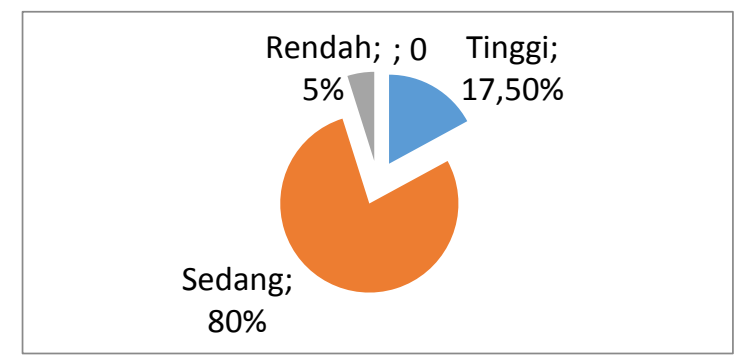

Gambar 2.Hasil kategorisasi skor subjek

terhadap skala iklim sekolah

Presepsi siswa terbentuk melalui proses pskilogis dalam diri siswa melalui panca indera. Manakala siswa mengamati segala sesuatu yang ada dilingkungan sekolahnya maka akan timbul kesan atau tanggapan melalui pengamatan yang telah dilakukan. Tanggapan sebagian bayangan terhadap iklim sekolah berlanjut membentuk persepsi positif atau negatif. Penilain siswa menjadi positif jika hasil pengamatan siswa menganggap kondisi sekolah sudah terbentuk aktifitas belajar yang kondusif, saling menghargai antara siswa maupun guru, adanya perhatian dari pimpinan dan adanya hubungan yang akrab, penuh pengertian, dan rasa kekeluargaan antara sivitas sekolah. Presepsi yang sudah terbentuk selanjutnya akan mempengaruh secara positif terhadap sikap dan perilaku siswa disekolah, siswa menjadi lebih bersemangat dalam belajar, dapat menjalin hubungan atau komunikasi yang harmonis dengan siswa lain dengan guru, adanya sikap saling menghargai dan saling menghormati. Kondisi ini secara tidak langsung akan membantu proses penyesuaian diri pada siswa. Dengan mempresepsikan iklim sekolah yang baik maka akan menekan perilaku emoseioanal dan masalah perilaku menyimpan seperti membolos sekolah.

Berdasarkan analisis secara parsial, terdapat pengaruh yang signifikan antara motivasi berprestasi terhadap perilaku membolos siswa dengan nilai signifikansinya $<0,05$. Sehingga disimpulkan semakin tinggi motivasi berprestasi siswa maka semakin rendah perilaku membolos. Atau dengan kata lain tinggi rendahnya perilaku membolos siswa dapat diprediksi dari tinggi rendahnya motivasi berprestasi siswa. Hasil penelitian ini sejalan dengan penelitian Nelsan (2009), yang mengatakan motivasi belajar siswa berpengaruh terhadap perilaku akademik siswa yang akhirnya berpengaruh terhadap peningkatan prestasi siswa.

Motivasi sangat diperlukan dalam proses belajar karena motivasi merupakan daya pendorong dari dalam diri siswa untuk memcapai prestasi. Motivasi berprestasi merupakan manifestasi dari keinginan yang dapat mempengaruhi perilaku untuk melakukan yang terbaik dalam aktivitas belajar. Siswa yang memiliki motivasi berprestasi yang tinggi akan menimbulkan kegiatan belajar yang menjamin kelangsungan dalam kegiatan belajar dan memberi arahan sehingga tujuan yang dicapai dengan hasil yang sebaik-baiknnya.

Berdasarkan hasil kategorisasi skor subjek terhadap skala motivasi berprestasi menunjukan bahwa hampir seluruh siswa termasuk dalam kategori sedang yaitu 75,5\% atau dari 200 subjek terdapat 157 siswa yang mempunyai motivasi berprestasi sedang. Sedangkan sisanya 43 siswa atau $24,5 \%$ memiliki motivasi berprestasi yang tinggi. Dengan demikian dapat dimaknai bahwa rata-rata siswa memiliki motivasi beprestasi yang sedang. Hal ini dapat dilihat pada gambar 3 berikut.

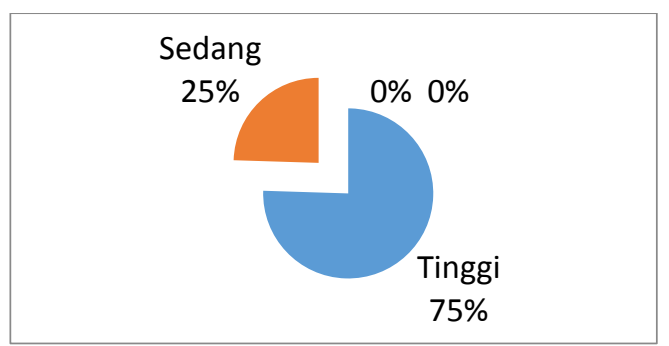

Gambar 3.Hasil kategorisasi skor subjek terhadap skala motivasi berprestasi

Pada dasarnya motivasi berfungsi sebagai suatu penguatan yang mendorong, mengerahkan siswa dalam belajar untuk mencapi prestasi. Dalam mencapai suatu prestasi tentu saja hanya bisa dilakukan ketika siswa bertanggung jawab menjalankan fungsinya sebagai pelajar yaitu dengan belajar yang tekun di sekolah dan dirumah, serta senantiasa hadir dan mengoptimalkan segala kemampuannya dalam aktifitas di sekolah. Siswa yang memiliki motivasi yang tinggi dalam belajar akan menunjukan keinginan yang besar dan perhatian yang penuh terhadap tugas-tugas belajar dan mengarahkan energi fisik maupun psikis terhadap kegiatan belajar tanpa merasa bosan dan lelah 
serta siswa akan berusaha mengatasi hambatanhambatan dalam upaya mencapai prestasinya. sebaliknya siswa yang memiliki motivasi untuk berprestasi yang rendah menampakan keenggananya untuk hadir disekolah, cepat bosan, dan berusaha menghindari proses pembelajaran di sekolah.

Sejalan dengan penelitian yang dilakukan Fitrianingsih (2013) yang mengemukakan bahwa siswa dengan motivasi belajar yang tinggi akan berdampak terhadap peningkatan perilaku akademik siswa seperti rajin masuk sekolah, rajin belajar dan sebagainya, hal ini akan membawa dampak pula terhadap prestasi siswa, dimana siswa memiliki motivasi berprestasi yang tinggi diharapkan dapat mempunyai kecendrungan perilaku membolos yang rendah. Djaali (2008) menyebutkan bahwa seorang pelajar dengan motivasi berprestasi yang kuat maka akan selalu melakukan sesutu dengan sebaik mungkin dan menghalau keinginannya untuk tidak hadir disekolah (membolos).

\section{Simpulan}

Berdasarkan uraian-uraian di atas maka diperoleh kesimpulan, Pertama,terdapat pengaruh yang sangat signifikan antara pola asuh permisif, iklim sekolah dan motivasi berprestasi terhadap perilaku membolos siswa. Kedua, ada pengaruh positif yang signifikan antara pola asuh permisif terhadap perilaku membolos. Artinya semakin tinggi pola asuh orang tua maka semaikin tinggi perilaku membolos siswa, sebaliknya semakin rendah pola asuh permisif maka semakin rendah pula perilaku membolos siswa. Ketiga, tidak ada pengaruh antara iklim sekolah terhadap perilaku membolos siswa. Keempat, ada pengaruh antara motivasi belajar terhadap perilaku membolos. Semakin tinggi motivasi berprestasi maka semakin berdah perilaku membolos, demikian sebaliknya semakin rendah motivasi berprestasi siswa maka semakin tinggi perilaku membolos.

Hasil penelitian ini dapat dijadikan sebagai informasi bagi orangtua dalam memberikan pola asuh yang efektif bagi anak. Bagi guru bimbingan dan konseling dapat dijadikan sebagai bahan pertimbangan dalam menyusun program layanan bimbingan dan konseling untuk mereduksi perilaku membolos siswa.

\section{Referensi}

Abdulkadir, S. (2014). Meminimalkan Perilaku Membolos Pada Siswa Kelas VII. 9. SMP Negeri 8 Gorontalo Melalui Layanan Bimbingan Kelompok. http://repository.ung.ac.id/skripsi. diakses pada tanggal 26 Mei 2015.

Aisyah. (2010). Pengaruh Pola Asuh Orang Tua Terhadap Tingkat Agresivitas Anak. Jurnal MEDTEK, 1(1), 68-74.

Aisyah, S. (2013). Hubungan Antara Pola Asuh Orang Tua dengan Perilaku Seksual Pernikahan Pada Remaja di SMK BATIK 1 Surakarta. Jurnal GASTER, 10(2), 214-224.

Almansur, M. G. (2009). Metodelogi Penelitian Pendidikan. Malang: UIN Press.

Arikunto, P. D. (2002). Prosedur Penelitian. Jakarta: Rineka.

Asnawi, S. (2002). Teori Motivasi. Jakarta: Studi Press.

Atkison, R. L. (1992). Pengantar Psikologi. Jilid II (Terjemahan Nurdjanah Taufik). Jakarta: Erlangga.

Austin, G. (2013). School Climate and the Truancy Cricis. http://schoolclimateconnection.org/blog/blog/. diakses pada tanggal 27 Febuari 2015.

Azwar, S. (2009). Reliabilitas dan Validitas. Yogyakarta: Pustaka Pelajar.

Azwar, S. (2010). Metode Penelitian. Yogyakarta: Pustaka Pelajar.

Azwar, S. (2012). Penyusunan Skala Psikologi. Yogyakarta: Pustaka Pelajar.

Azwar, S. (2013). Reliabilitas dan Validitas. Yogyakarta: Pustaka Pelajar.

Barakatu, A. R. (2007). Membangun Motivasi Berprestasi: Pengembangan Self Efficacy dan Penerapannya dalam Dunia Pendidikan. Jurnal Lentera Pendidikan,10(1), 34-51.

Bazemore, G. S. (2004). Scared Smart or Bord Straight? Testing Deterrence Logic in an Evaluation of Police-Led Truancy Intervention. Journal of Justice Quarterly, 21(2), 271-299.

Bee, H. A. (2007). The Developing Child Eleventh Edition. USA: Paramount Publishing.

Corolaso, B. (2006). Penindas, Tertindas, dan Penonton. Jakarta: PT Serambi Ilmu Semesta. 
Damayanti, A. F. (2013). Studi tentang Perilaku Membolos pada Siswa SMA Swasta di Surabaya. Jurnal BK UNESA,3(1), 454-461.

Dimiyanti, M. M. (1990). Belajar dan Pembelajaran. Jakarta: PT Rineka Cipta.

Djaali, H. M. (2007). Pengukuran dalam Pendidikan. Jakarta: Studi Press

Dorcas, O. F. (2013). Truancy and Academic Performance of Secondary School Student in Soutwestern Nigeria: Implications for Counselling. International Journal for Cross Diciplinary Subjects in Education,3(1), 14241428.

Ellena, R. C. (2014). Perbedaan Self-Regulated Learning Siswa SMA Ditinjau dari Presepsi Terhadap Pola Asuh Orang Tua (A Comparation Study of Senior Higt School Student Self- Regulation Learning Based on Their Preception of Parenting). Jurnal Psikologi Pendidikan Perkembangan,3(3), 234-245.

Faturahman, R. (2011). Pengaruh Motivasi Berprestasi Terhadap Motivasi Belajar, Pelaksanaan Prakering dan Pencapaian Kompetensi Mata Pelajaran Produktif Teknik Kendaraan. Jurnal INVOTEC,2(8), 175-188.

Gunarsa, S. D. (2000). Psikologi Perkembangan Anak dan Remaja Cetakan ke-12. Jakarta: Gunung Mulia.

Hamzah, B. U. (2008). Teori Motivasi dan Pengukurannya Analisis Bidang Pendidikan. Jakarta: Bumi Aksara.

Hamzah, B. U. (2014). Teori Motivasi dan Pengukurannya. Jakarta: Bumi Aksara.

Haward, E. H. (1987). Handbook for Conditing School Climate Improvement Project. Indiana: The Phy Delta Kappa Educational Fundation.

Hurlock, E. B. (1997). Psikologi Perkembangan. Jakarta: Erlangga.

Indiyani, A. S. (2014). Penerapan Konseling Behavior dengan Teknik Penguatan Positif sebagai Upaya untuk Menimalisasi Perilaku Membolos pada Siswa Kelas X.1 SMA Negeri 1 Sawan Tahun ajaran 2013/2014. Jurnal Bimbingan Koseling,2(1), 1-18.

Joshi, S. D. (2013). Home Environment and Achievement Motivation of Adolescence. Sosial Science International, 29: 105-120.

Kartono, K. (2003). Bimbingan Bagi Anak dan Remaja Bermasalah. Jakarta: Rajawali Press.
Kearney, C. A. (2001). School Refusal Behavior in Youth. A Functional Approach to Assessment and Treatment. Washington DC: American Psychological Association.

Louskas, A. S. (2004). Examining the Moderating Role of Perceived School Climate in Early Adolescent Adjustment. Journal of Research on Adolescence, 14(2),109-233.

Mahmuda. (2012). Mengurangi Perilaku Membolos Siswa dengan Menggunakan Layanan Behavior. Jurnal Ilmiah Pendidikan Bimbingan dan Konseling IKIP Veteran Semarang, 2(1), 63-73.

Mardatila, A. (2014). Hubungan Pola Asuh Orang Tua Dengan Kecerdasan Anak Pra Sekolah (36 tahun) di TK Budi Utama Jorong Sebrang Parit Kota Tengah Batu Hampa Kecamatan Kalibiru Kabupaten Lima Puluh Kota. Jurnal Pola Asuh,2(1), 23-30.

Mariana, L. (2012). Hubungan antara Persepsi Terhadap Standar Kompetensi Lulusan dan Motivasi Berprestasi Dengan Prokartinasi Akademik. Tesis tidak dipublikasikan. Magister Psikologi Universitas Gadja Mada, Yogyakarta.

Marlina, L. (2010). Hubungan antara Persepsi Lingkungan Sekolah dan Motivasi Berprestasi Terhadap Kecenderungan Perilaku Membolos Pelajar. Tesis tidak dipublikasikan. Magister Psikologi Universitas Gadja Mada, Yogyakarta.

Mulyadi, S. (1997). Anakku, Sahabatku, dan Guruku. Jakarta: Erlangga.

Murniati, L. (2008). Manejemen Statistik Peran Kelapa Sekolah dalam Pemberdayaan. Medan: CV Perdana Muliya Sarana.

Mussen, P. H. (1994). Perkembangan dan Kepribadian Anak Edisi Enam (terjemahan). Jakarta: Arcan.

Nelsan. (2009). Involve on Student Academic Behavior Through Motivation, Self- Efficacy and Value-Expectation: An Action Research Project to Improve Learning of Adge.

Nurdin, A. (2014). Strategi Pengurusan Konflik Pengetua Terhadap Iklim Sekolah Menengah di Indonesia. Proceedings of the Accademic Simposium on Integriting Knowledge. (Naskah Publikasi). UIN Makssar. http://books.google.co.id. Diakses pada tanggal 26 Mei 2015. 
Paramitasari, T. (2012). Pengaruh Persepsi Pola Asuh Permisif Orang Tua Terhadap Perilaku Membolos. Journal Education Psychology,2, 252-634.

Prayitno, H. A. (2009). Dasar-dasar BIMBINGAN dan Konseling. Jakarta: Rineka Cipta.

Reid, K. (2004). A long-Term Strategic Approach to Tackling Truancy and Absenteeism From School: The SSTG scheme. Journal of Guidance and Counseling, 32(1), 57-74.

Sadirman, A. M. (1996). Interaksi dan Motivasi Belajar Mengajar Pedomanan Bagi Guru dan Calon Guru. Jakarta: PT Grafindo Perkasa.

Salim, P. (1991). Kamus Bahasa Indonesia Kontemporer. Jakarta: Moder English Press.

Sanjiwani, N. B. (2014). Pola Asuh Permisif Ibu dan Perilaku Merokok Pada Remaja Laki-Laki di SMA Negeri 1 Samarapura. Jurnal Psikologi Udayana, 1(2), 344-354.

Santrock, J. W. (2002). Life Span Development Perkembangan Masa Hidup. Jilid 1 Terjemahan T Hermaya. Jakarta: Erlangga.

Santrock, J. W. (2003). Adolescent: Perkembangan Remaja Edisi Keenam. Terjemahan Shinto B. Adler Sherly Saragih. Jakarta: Erlangga.

Sarwono, W. S. (2012). Psikologi Remaja. Jakarta: PT Raja Gravindo.

Sheppard, A. (2009). School Attendance and Attainment: Poor Attenders Perceptions of Parental Involvement in Their Education. Journal of Special Education,35(2), 104-111.
Slameto. (2003). Belajar dan Faktor-faktor yang Mempengaruhinya. Jakarta: Rineka Cipta.

Slavin, R. E. (2013). Psikologi Pendidikan Teori dan Praktek Jilid 2. Jakarta: PT Indeks.

Sugiharti, E. (2012). Hubungan Antara Motivasi Berprestasi dan Konsep Diri dengan Prestasi Belajar Siswa di SMK 1 Kabupaten Majalangka. Tesis tidak dipublikasikan. IAIN Syeikh Nurjadi, Cirebon.

Suhartana. (2013). Hubungan Presepsi guru, Motivasi Berprestasi dan prestasi Belajar Sejarah dengan Regulasi Diri Sebagai Mediator Pada Siswa Kelas IX SMA Pengasih Kulonprogo. Tesis tidak dipublikasikan. Universitas Ahmad Dahlan, Yogyakata.

Thoha, M. (1994). Perilaku Organisasi dan Pola Organisasi. Jakarta: Rajawali.

Trujillo, A. L. (2006). School Truancy: A Case Study of a Successful Truancy Reduction Model in the Public School. Journal of Juvenile Law and Policy, 10 (1), 69-95.

Usman, I. (2013). Perilaku Bullying Ditinjau dari peran Kelompok, Teman Sebaya, dan Iklim Sekolah pada Siswa SMA di Kota Gorontalo. Jurnal Bimbingan Konseling, 2(1), 5-14.

Wingkel, W. S. (1991). Psikologi Pengajaran. Jakarta: PT Grasindo.

www.jogja.solopos.com

www.kabarkota.com

Yusuf, S. (2007). Psikologi Perkembangan Anak dan Remaja. Bandung: Remaja Rosdakarya. 